\title{
Ambient levels of volatile organic compounds in the vicinity of petrochemical industrial area of Yokohama, Japan
}

\author{
Vasu Tiwari • Yoshimichi Hanai • Shigeki Masunaga
}

Received: 2 July 2009 /Accepted: 10 September 2009 /Published online: 28 October 2009

(C) The Author(s) 2009. This article is published with open access at Springerlink.com

\begin{abstract}
Urban ambient air concentrations of 39 aromatic (including benzene, toluene, and xylenes) and aliphatic volatile organic compounds (VOCs) were measured in Yokohama city, Japan. Yokohama city was selected as a case study to assess the amount of VOC released from Industrial area to characterize the ambient air quality with respect to VOC as well as to know the impact of petrochemical storage facilities on local air quality. For this purpose, ambient air samples were collected (from June 2007 to November 2008) at six selected locations which are designated as industrial, residential, or commercial areas. To find out the diurnal variations of VOC, hourly nighttime sampling was carried out for three nights at one of the industrial locations (Shiohama). Samples were analyzed using gas chromatographic system (GCFID). Results show strong variation between day and nighttime concentrations and among the seasons. Aliphatic fractions were most abundant, suggesting petrochemical storage facilities as the major source of atmospheric hydrocarbons. High concentrations of benzene, toluene, ethyl benzene, and xylene (BTEX) were observed at industrial locations. BTEX showed strong diurnal variation which is attributed to change in meteorology. During our campaign, low ambient VOC concentrations were observed at the residential site.
\end{abstract}

Keywords BTEX - Volatile organic compounds · Ozone formation potential $\cdot$ Interspecific ratio $\cdot$ Health risk

V. Tiwari $(\varangle) \cdot$ Y. Hanai $\cdot$ S. Masunaga

Department of Environment and Information Sciences, Yokohama

National University,

Yokohama 240-8501, Japan

e-mail: vasutiwari@gmail.com

\section{Introduction}

The importance of organic compounds produced due to anthropogenic activities into the atmosphere was recognized about 50 years ago by Haagen-Smit in his studies of Los Angeles' smog (Derwent 1995). Volatile organic compounds (VOCs), which are the main group of hydrocarbons in the atmosphere, play an important role in the formation of ozone and other photochemical oxidants in the troposphere (Kalabokas et al. 2001). Benzene, toluene, ethyl benzene, and xylene are the most typical components of VOC pollution in air (Chattopadhyay et al. 1997; Srivastava et al. 2005a, b). Several effects of VOCs are recognized such as their contribution to stratospheric ozone depletion, toxic and carcinogenic human health effects, and enhancement of the global greenhouse effect (Cetin et al. 2003). Petroleum refineries and petrochemical storage facilities are generally large installations. Their operation is associated with the emission of various hydrocarbons into the atmosphere, mainly originated from the production processes, the storage tanks, and the waste areas (Kalabokas et al. 2001). Studies on long-term monitoring of toxic pollutants from industrial facilities confirm a significant exposure for inhabitants of these areas (Suleimanov 1997). Once VOCs are emitted into the atmosphere, they cause not only pollution problem on local scale but also play an important role on regional scale like acid rain, photochemical ozone formation initiated by the reaction with $\mathrm{OH}$ radicals in the troposphere in the presence of nitrogen oxides and sunlight (Finlayson-Pitts and Pitts 1986).

Hydrocarbons present in urban atmosphere may result from a number of industrial activities such as petrochemical process, storage, distribution, paint, solvent, combustion processes, and motor vehicle exhaust. In urban areas, a group of aromatic VOCs (benzene, toluene, ethyl benzene, 
and xylenes) collectively called as BTEX constitute up to $60 \%$ of non-methane VOCs (Lee et al. 2002); among these VOCs, benzene is an important representative of aromatic hydrocarbons and has been a high priority urban air pollutant for assessment (Brocco et al. 1997; Coursimault et al. 1995; Pfeffer et al. 1995). VOCs modify the oxidizing capacity of the atmosphere by reaction with hydroxyl radicals in the presence of $\mathrm{NO}_{\mathrm{x}}$ to form ozone (Atkinson 2000).

Though the VOCs are regularly monitored by governmental agencies in Japan, most of the time, the monitoring is limited to major representative VOCs (such as BTEX) only. Ambient air quality standards are not yet set for many of the VOC species (such as ethyl benzene). There are few studies that have reported VOC levels in Japanese cities so far (Yamamoto et al. 1988, 2000; Olansandan et al. 1999; Ohura et al. 2006; Kume et al. 2008).

In this study, field measurements of selected atmospheric VOCs were performed (from June 2007 to November 2008) at selected six locations (Negishi, Honmoku, Shiohama, Minezawa, Sakuragicho, and Tsurumi) in Yokohama city region covering different seasons. During the campaign, a total number of 69 ambient air samples were collected and analyzed for 39 VOCs. The aim of the study was to determine the atmospheric pollution levels of aliphatic and aromatic VOCs. The present study is an attempt to envisage and investigate the impact of the presence of petrochemical storage facilities on local air quality and associated health risk to the local population. During each round of ambient air sampling, meteorological parameters such as temperature, wind speed, and wind direction were also recorded. Characterization of the VOCs in terms of their interspecies correlation and concentration ratios in ambient air at different locations was carried out. The seasonal and spatial variations of ambient volatile organic compounds were analyzed. Ozone formation potentials of BTEX were also calculated to know the contribution of these species to the atmospheric ozone formation.

\section{Methodology}

The study area

Yokohama, the capital city of Kanagawa Prefecture, is the second largest city of Japan. It is situated on the western coast of Tokyo Bay and lies $30 \mathrm{~km}$ from Tokyo, the capital of Japan, in the middle of the Japanese main island, Honshu, facing the Pacific Ocean. It has a geographic area of $434.98 \mathrm{~km}^{2}$ with a population of 3.6 million and a population density of $8,401 \mathrm{~km}^{-2}$, which makes it Japan's largest incorporated city. Yokohama city stretches in eastwest width approximately $23.63 \mathrm{~km}$ and north-south width approximately $31.11 \mathrm{~km}$. It is situated at latitude of $35^{\circ} 27^{\prime} \mathrm{N}$ and the longitude of $139^{\circ} 38^{\prime} \mathrm{E}$ and has high precipitation in September $(232.4 \mathrm{~mm})$ and October $(184.9 \mathrm{~mm})$ months. The mean annual rainfall in Yokohama is about $135.7 \mathrm{~mm}$. January is the coldest month with a mean monthly temperature at $5.6^{\circ} \mathrm{C}$. August is the hottest month with a mean monthly temperature of $26.4^{\circ} \mathrm{C}$. The average annual temperature is $15.5^{\circ} \mathrm{C}$.

\section{Description of sampling sites}

We have selected six locations of different categories with varied local activities including traffic density. The sampling locations are shown in the map of Yokohama (Fig. 1). Negishi (site 1), Honmoku (site 2), and Shiohama (site 3) are in the industrial areas located on the coast of the Yokohama city especially with petrochemical industrial activity. Minezawa (site 4) is a residential site with good vegetation cover and a patch of agricultural area. It is located next to Yokohama National University campus. Traffic flow is low at this location, but it has the influence of the surrounding area. Sakuragicho (site 5) is a commercial area with good amount of traffic moment. In addition to traffic, the air quality at this area is also influenced by the adjacent industrial areas (Negishi and Honmoku). Tsurumi (site 6) is a residential area which is located adjacent to Shiohama industrial area. The air quality at this location is influenced by traffic as well as the industrial activities. In this study, we have assumed the contribution of VOC due to fuel-driven vehicles as a common contributor to ambient air with varying magnitude at all our selected study locations.

\section{Sampling and analysis}

Ambient air quality samples were collected during the period of June 2007 to November 2008. Sampling was carried out by active grab sampling method using a hand-operated pump. Air samples at each of the six sampling sites were collected in 10-L Flek polyester bags. At the end of each sampling round, samples were transported to the laboratory and analyzed by gas chromatography-flame ionization detector (GC-FID) technique. A total of 69 samples were collected during the campaign. The external calibration standard mixture of 38 VOCs was purchased from Spelco, Japan and was used for calibration. The calibration standards were prepared by diluting the stock standard mixtures of 38 VOCs to 20-ppb level. Then, the working standard in parts per billion level was prepared from the standard concentrations.

Samples were analyzed by GC (Hewlett-Packard 5890 series II) equipped with FID. The analytical column was a 


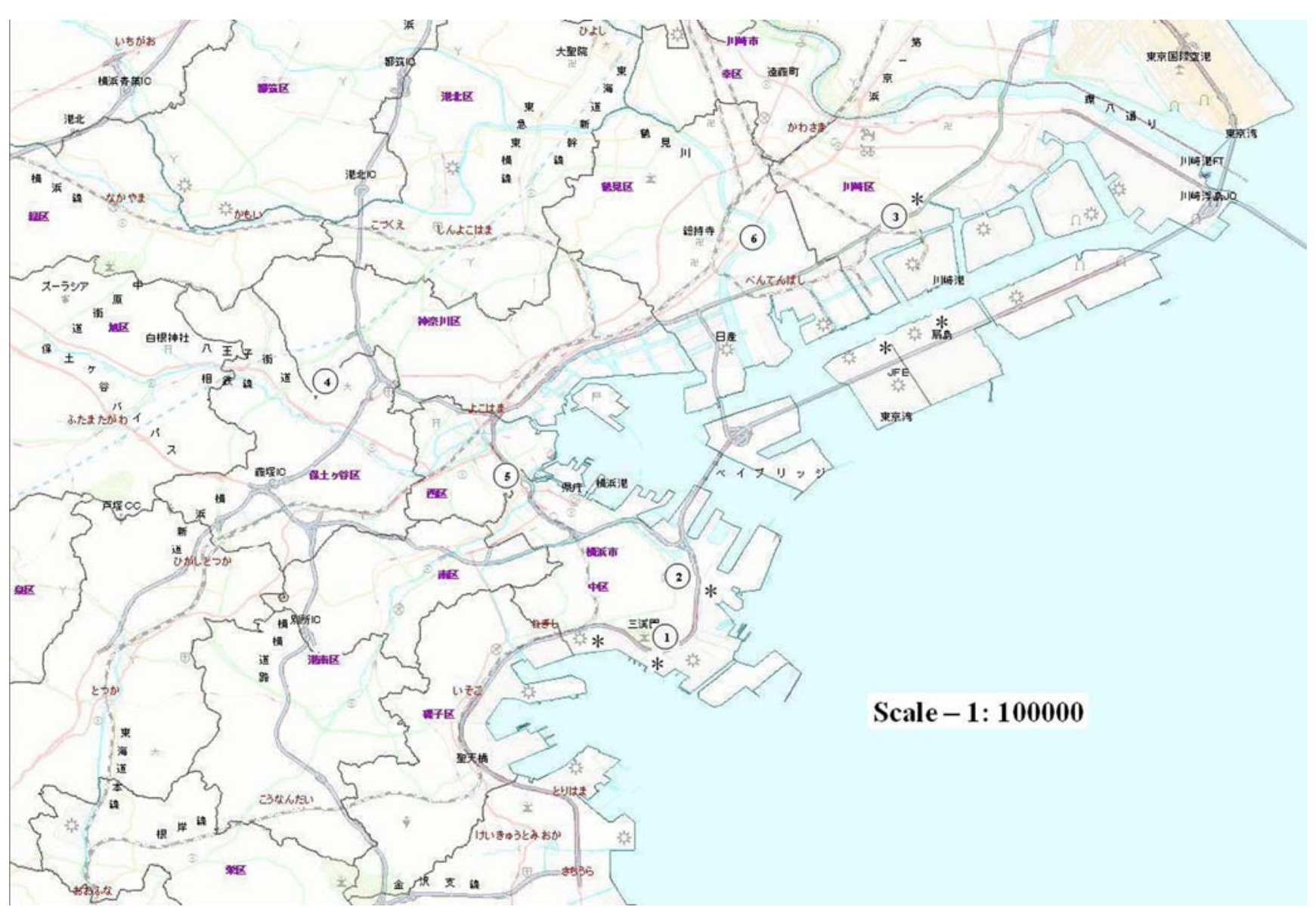

Fig. 1 Map of Yokohama showing the sampling locations (locations are shown in circled numbers 1-6; petrochemical/chemical industry shown as asterisk)

$30 \mathrm{~m} \times 0.33 \mathrm{~mm}(\mathrm{HP}-5)$ and total chromatopack software. The temperature was programmed for $50^{\circ} \mathrm{C}$ hold for $4 \mathrm{~min}$ and ramped to $250^{\circ} \mathrm{C}$ at $10^{\circ} \mathrm{C} \mathrm{min}{ }^{-1}$ rate with $10 \mathrm{~min}$ hold at $250^{\circ} \mathrm{C}$. Nitrogen was used as a carrier gas with flow rate of $1 \mathrm{~mL} \mathrm{~min}{ }^{-1}$ and split ratio of 1:10.

For analyzing high boiling point compounds (up to $250^{\circ} \mathrm{C}$ ), we used Tenax-TA tubes for concentrating air samples with a liquid nitrogen cryogenic trap held at $-196^{\circ} \mathrm{C}$; then, the cryogenic trap was consequently heated up to a temperature of $50^{\circ} \mathrm{C}$, and the compounds were injected to the analytical column of a gas chromatograph. The analytical column was a $30 \mathrm{~m} \times 0.33 \mathrm{~mm}$ (HP-5 column).

During each sampling round, prior to the sampling, the sampling bags were flushed twice with ultrapure nitrogen gas. Quality assurance and quality control measures were taken. It included laboratory and field blanks during each sampling round. The concentrations were below detection limit in blanks. The coefficient of variation for aliphatic and aromatic hydrocarbons were observed to be well below $5 \%$ $(<5 \%)$. Slightly higher percentage of coefficient of variation was observed (5.5-5.98\%) for 1,2,4-trimethyl benzene and 1,3,5-trimethyl benzene. The coefficient of variation results for hourly air samples $(150 \mathrm{~L})$ during a time period of $24 \mathrm{~h}$ were shown in Table 1.

During analysis of air samples, under the same analytical conditions, different contaminants may be generated due to vaporization from sampling bag, such as Tedlar bag generated phenol and $N, N$-dimethylacetamide (Hanai et al. 1981).

We used Flek polyester bags for the collection of ambient air samples in this study. From the results of a comparative study between Tedlar bag and Flek polyester bag (the results provided by the manufacturer of Flek polyester bag; Japanese web site www.shoshu. com), it was found that Flek polyester bag was more consistent than Tedlar bag. This comparative study investigated the change in total hydrocarbon standard concentration using these two different types of bags with respect to time $(0,1,2,4$, and $8 \mathrm{~h})$. The comparative study illustrates that the difference in results (from 0 to $8 \mathrm{~h}$ ) was observed high (about $640 \mathrm{ppb}$ ) for Tedlar bag, while less difference was observed (30 ppb) for Flek polyester bag. It indicated less vaporization of contaminants when Flek polyester bag was used. 
Table 1 Coefficient of variation of hourly samples collected for $24 \mathrm{~h}$

\begin{tabular}{lccccc}
\hline Compound & \multicolumn{2}{l}{ Peak area } & & \multicolumn{2}{l}{ Peak time } \\
\cline { 2 - 3 } & Mean \pm SD & Coefficient of variation (\%) & & Mean \pm SD & Coefficient of variation (\%) \\
\hline Benzene & $627.11 \pm 29.54$ & 4.71 & $25.52 \pm 0.031$ & 0.13 \\
Toluene & $979.94 \pm 45.23$ & 4.62 & $27.80 \pm 0.032$ & 0.11 \\
Ethyl benzene & $172.22 \pm 8.00$ & 4.64 & $31.45 \pm 0.025$ & 0.078 \\
$m, p$-Xylene & $497.77 \pm 16.06$ & 3.23 & $31.81 \pm 0.024$ & 0.075 \\
$o$-Xylene & $224.77 \pm 10.99$ & 4.89 & $32.92 \pm 0.021$ & 0.064 \\
$1,3,5$-Trimethly benzene & $70.53 \pm 4.22$ & 5.98 & $36.78 \pm 0.015$ & 0.040 \\
$1,2,4$-Trimethly benzene & $230.30 \pm 12.66$ & 5.50 & $38.11 \pm 0.014$ & 0.036 \\
\hline
\end{tabular}

Y. Hanai et al., Bulletin of Institute of Environmental Science and Technology, Yokohama National University

\section{Results and discussion}

VOC concentrations in industrial and residential locations

Various studies have been conducted by several authors at different industrial cities in order to understand the airborne VOC distributions and the source correlations (Chang et al. 2005; Ohura et al. 2006; Hsieh and Tsai 2003). VOCs emitted from industrial sources to the atmosphere may cause pollution on a local scale. In an industrial city, VOC emissions could not only be resulted from the industrial source but also be affected by surrounding traffic sources (Liu et al. 2008). Mean and standard deviation of daytime concentrations of VOCs measured at six locations in Yokohama city are summarized in Table 2. Among aliphatic hydrocarbons, propane, isobutane, $n$-butane, $n$ pentane isopentane, and ethylene were found to be abundant at industrial locations. It was observed that the aliphatic fraction was the most abundant group, indicating petrochemical industrial activity as the major source of atmospheric hydrocarbons (Gariazzo et al. 2005). From Table 2, it can be observed that the maximum concentrations of VOCs were found at the industrial areas. This might be due to the evaporations and petrochemical industrial activities. The minimum levels were detected at residential site (Minezawa).

Benzene is a carcinogenic compound causing leukemia. The World Health Organization has estimated that a lifetime exposure of $1 \mu \mathrm{g} / \mathrm{m}^{3}$ benzene through inhalation leads to about six additional cases of leukemia per million inhabitants (WHO 1999). In our study, we found that the mean concentration of benzene in Yokohama city (considering all six locations) was $2.79 \mu \mathrm{g} / \mathrm{m}^{3}$. For this city with a population of about 3.6 million, about additional 22 cancer cases of leukemia would be expected (assuming continuous inhalation for 70 years and indoor concentrations is the same as outdoor concentrations). However, the distribution of population is not equal at industrial and residential areas.
Most of the population is concentrated at residential areas compared to industrial areas. Hence, the actual risk is much more less than the current estimate. The contributions of aliphatic and aromatic fraction of VOCs at all six locations including the nighttime concentrations at Shiohama are represented graphically in Fig. 2. It was observed that aliphatic fraction was dominant at all the study locations. From this figure, it can be noticed that the composition of VOCs is similar at site 2 , site 5 , and site 6 .

The major source of $n$-butane in the urban atmosphere is gasoline evaporative emission and is a tracer of gasoline use. At industrial sites, observed $n$-butane concentrations were in the range of 3.5-6 ppb. The sources of isobutane are consumer products and petrochemical refining in addition to gasoline evaporation. Among the industrial locations, relatively high concentration of isobutane was observed at Shiohama (site 3). Propane comes into the ambient air from LPG and natural gas usage besides oil and gas production. The observed high concentration of propane at the industrial location Shiohama (site 3) was $24.7 \mathrm{ppb}$.

\section{Diurnal and spatial variations of VOCs}

To know the pollutant spatial pattern with respect to time, we have conducted nighttime sampling at the industrial location, Shiohama (site 3). Hourly ambient air samples were collected beginning from 11:00 pm to 5:00 am and again at 10:00 am for 3 days $(n=21)$. The diurnal variations of BTEX are shown in Fig. 3. The variations were found to follow a similar pattern, indicating that these compounds have a similar source and dispersion pattern. The observed ambient concentrations increased during midnight (11:00 pm-1:00 am) and then decreased during 1:00 to 2:00 am; after that, they showed a steady increasing pattern then increased at 10:00 am. High concentration of benzene $\left(8 \mu \mathrm{g} / \mathrm{m}^{3}\right), \quad m, p$-xylene $\left(10.8 \mu \mathrm{g} / \mathrm{m}^{3}\right)$ were observed at midnight (11:00 pm-1:00 am), and toluene $\left(19.3 \mu \mathrm{g} / \mathrm{m}^{3}\right)$ 
Table 2 Summary of VOCs (mean \pm SD in ppb) at six locations in Yokohama city

\begin{tabular}{|c|c|c|c|c|c|c|c|}
\hline \multirow[t]{3}{*}{ VOCs } & \multicolumn{7}{|c|}{ Locations } \\
\hline & \multirow{2}{*}{$\begin{array}{l}\text { Area } \\
\text { Name } \\
\text { Site }\end{array}$} & \multicolumn{3}{|l|}{ Industrial } & \multicolumn{2}{|l|}{ Residential } & \multirow{2}{*}{$\begin{array}{l}\text { Commercial } \\
\text { Sakuragicho } \\
\text { Site } 5(n=8)\end{array}$} \\
\hline & & $\begin{array}{l}\text { Negishi } \\
\text { Site } 1(n=8)\end{array}$ & $\begin{array}{l}\text { Honmoku } \\
\text { Site } 2(n=8)\end{array}$ & $\begin{array}{l}\text { Shiohama } \\
\text { Site } 3(n=8)\end{array}$ & $\begin{array}{l}\text { Minezawa } \\
\text { Site } 4(n=8)\end{array}$ & $\begin{array}{l}\text { Tsurumi } \\
\text { Site } 6(n=8)\end{array}$ & \\
\hline \multicolumn{2}{|c|}{ Ethane } & $2.5 \pm 1.1$ & $1.8 \pm 0.7$ & $6.7 \pm 5.3$ & $2.1 \pm 0.7$ & $2.7 \pm 1.3$ & $2.4 \pm 1.3$ \\
\hline \multicolumn{2}{|c|}{ Propane } & $5.5 \pm 5.7$ & $2.1 \pm 1.3$ & $24.7 \pm 55$ & $1.9 \pm 1.2$ & $5.0 \pm 5.3$ & $2.8 \pm 2.0$ \\
\hline \multicolumn{2}{|c|}{ Isobutane } & $2.1 \pm 1.1$ & $1.8 \pm 2.3$ & $4.6 \pm 3.4$ & $0.9 \pm 0.7$ & $1.0 \pm 0.9$ & $1.9 \pm 3.1$ \\
\hline \multicolumn{2}{|c|}{$n$-Butane } & $5.3 \pm 4.2$ & $3.5 \pm 4.1$ & $6.0 \pm 4.4$ & $1.5 \pm 1.2$ & $1.6 \pm 1.3$ & $3.8 \pm 6.6$ \\
\hline \multicolumn{2}{|c|}{ Isopentane } & $7.2 \pm 8.0$ & $3.4 \pm 4.8$ & $3.7 \pm 3.1$ & $1.4 \pm 1.1$ & $1.4 \pm 1.2$ & $4.2 \pm 7.7$ \\
\hline \multicolumn{2}{|c|}{$n$-Pentane } & $3.2 \pm 3.2$ & $1.8 \pm 2.9$ & $2.6 \pm 3.0$ & $0.6 \pm 0.6$ & $0.8 \pm 0.7$ & $1.5 \pm 3.1$ \\
\hline \multicolumn{2}{|c|}{ 2-Methyl pentane } & $1.4 \pm 1.2$ & $1.8 \pm 3.1$ & $1.2 \pm 1.4$ & $0.4 \pm 0.4$ & $0.5 \pm 0.4$ & $0.9 \pm 1.3$ \\
\hline \multicolumn{2}{|c|}{ 3-Methyl pentane } & $0.7 \pm 0.5$ & $0.6 \pm 0.9$ & $0.5 \pm 0.4$ & $0.3 \pm 0.4$ & $0.3 \pm 0.3$ & $0.4 \pm 0.4$ \\
\hline \multicolumn{2}{|c|}{$n$-Hexane } & $1.7 \pm 0.9$ & $1.1 \pm 0.5$ & $2.4 \pm 1.9$ & $0.7 \pm 0.4$ & $1.2 \pm 1.2$ & $1.2 \pm 0.9$ \\
\hline \multicolumn{2}{|c|}{ Methylcyclopentane } & $0.4 \pm 0.3$ & $0.3 \pm 0.2$ & $1.3 \pm 1.7$ & $0.2 \pm 0.1$ & $0.2 \pm 0.2$ & $0.3 \pm 0.3$ \\
\hline \multicolumn{2}{|c|}{$n$-Heptane } & $0.3 \pm 0.3$ & $0.2 \pm 0.1$ & $0.4 \pm 0.3$ & $0.2 \pm 0.1$ & $0.2 \pm 0.1$ & $0.2 \pm 0.1$ \\
\hline \multicolumn{2}{|c|}{$n$-Octane } & $0.3 \pm 0.2$ & $0.1 \pm 0.05$ & $0.2 \pm 0.1$ & $0.1 \pm 0$ & $0.1 \pm 0.1$ & $0.1 \pm 0.04$ \\
\hline \multicolumn{2}{|c|}{$n$-Nonane } & $0.4 \pm 0.4$ & $0.2 \pm 0.1$ & $0.2 \pm 0.2$ & $0.1 \pm 0.04$ & $0.1 \pm 0.1$ & $0.2 \pm 0.1$ \\
\hline \multicolumn{2}{|c|}{$n$-Decane } & $0.4 \pm 0.2$ & $0.2 \pm 0.1$ & $0.2 \pm 0.1$ & $0.1 \pm 0.05$ & $0.2 \pm 0.1$ & $0.2 \pm 0.1$ \\
\hline \multicolumn{2}{|c|}{$n$-Undecane } & $0.2 \pm 0.1$ & $0.1 \pm 0.1$ & $0.2 \pm 0.2$ & $0.1 \pm 0.04$ & $0.2 \pm 0.1$ & $0.2 \pm 0.1$ \\
\hline \multicolumn{2}{|c|}{$n$-Dodecane } & $0.1 \pm 0.1$ & $0.1 \pm 0$ & $0.2 \pm 0.1$ & $0.1 \pm 0$ & $0.1 \pm 0.1$ & $0.1 \pm 0.04$ \\
\hline \multicolumn{2}{|c|}{$n$-Tridecane } & $0.2 \pm 0.1$ & $0.1 \pm 0.04$ & $0.2 \pm 0.1$ & $0.1 \pm 0$ & $0.1 \pm 0.1$ & $0.1 \pm 0.04$ \\
\hline \multicolumn{2}{|c|}{$n$-Tetradecane } & $0.2 \pm 0.1$ & $0.2 \pm 0.1$ & $0.2 \pm 0.1$ & $0.1 \pm 0.1$ & $0.2 \pm 0.1$ & $0.2 \pm 0.1$ \\
\hline Ethyl & & $3.9 \pm 3.4$ & $4.0 \pm 2.5$ & $11.2 \pm 6.9$ & $3.0 \pm 1.9$ & $4.8 \pm 3.2$ & $5.0 \pm 4.1$ \\
\hline Acety & & $1.5 \pm 1.4$ & $1.7 \pm 1.1$ & $2.4 \pm 1.7$ & $1.7 \pm 0.8$ & $2.0 \pm 1.8$ & $2.9 \pm 3.1$ \\
\hline Propy & & $0.8 \pm 0.6$ & $2.2 \pm 3.1$ & $2.0 \pm 0.7$ & $2.4 \pm 5.1$ & $1.0 \pm 1.0$ & $1.2 \pm 1.4$ \\
\hline 1,Isob & & $0.4 \pm 0.2$ & $0.4 \pm 0.5$ & $2.0 \pm 3.0$ & $0.2 \pm 0.2$ & $0.4 \pm 0.5$ & $0.4 \pm 0.5$ \\
\hline Benze & & $0.7 \pm 0.4$ & $0.4 \pm 0.3$ & $2.1 \pm 2.7$ & $0.4 \pm 0.3$ & $0.9 \pm 0.8$ & $0.7 \pm 0.6$ \\
\hline Tolue & & $3.1 \pm 1.7$ & $1.6 \pm 0.6$ & $5.2 \pm 5.7$ & $1.9 \pm 1.3$ & $2.2 \pm 1.5$ & $2.2 \pm 1.4$ \\
\hline Ethyl & & $0.8 \pm 0.6$ & $0.7 \pm 0.6$ & $2.9 \pm 3.7$ & $0.5 \pm 0.3$ & $0.9 \pm 0.6$ & $0.5 \pm 0.3$ \\
\hline$m, p-X$ & & $0.8 \pm 0.5$ & $0.5 \pm 0.3$ & $2.1 \pm 2.3$ & $0.4 \pm 0.3$ & $0.7 \pm 0.5$ & $0.6 \pm 0.4$ \\
\hline$o-\mathrm{Xyl}$ & & $0.4 \pm 0.2$ & $0.3 \pm 0.2$ & $0.7 \pm 0.5$ & $0.2 \pm 0.1$ & $0.3 \pm 0.2$ & $0.3 \pm 0.2$ \\
\hline$m$-Eth & & $0.3 \pm 0.1$ & $0.2 \pm 0.1$ & $0.2 \pm 0.1$ & $0.1 \pm 0.1$ & $0.1 \pm 0.1$ & $0.2 \pm 0.1$ \\
\hline$p$-Eth & & $0.3 \pm 0.1$ & $0.2 \pm 0.1$ & $0.2 \pm 0.1$ & $0.2 \pm 0.1$ & $0.2 \pm 0.1$ & $0.2 \pm 0.1$ \\
\hline$o$-Eth & & $0.2 \pm 0.1$ & $0.1 \pm 0.05$ & $0.1 \pm 0.1$ & $0.1 \pm 0.1$ & $0.1 \pm 0.1$ & $0.1 \pm 0.1$ \\
\hline $1,3,5-$ & oenzene & $0.1 \pm 0.1$ & $0.1 \pm 0.1$ & $0.1 \pm 0.1$ & $0.1 \pm 0.1$ & $0.1 \pm 0.05$ & $0.1 \pm 0.1$ \\
\hline $1,2,4-$ & genzene & $0.5 \pm 0.3$ & $0.3 \pm 0.2$ & $0.3 \pm 0.3$ & $0.2 \pm 0.1$ & $0.2 \pm 0.2$ & $0.3 \pm 0.2$ \\
\hline Napth & & $0.2 \pm 0.1$ & $0.2 \pm 0.1$ & $0.2 \pm 0.1$ & $0.2 \pm 0.1$ & $0.2 \pm 0.1$ & $0.2 \pm 0.1$ \\
\hline Ethyl & & $0.4 \pm 0.2$ & $0.6 \pm 0.5$ & $0.6 \pm 0.5$ & $0.6 \pm 0.5$ & $0.6 \pm 0.7$ & $0.6 \pm 0.6$ \\
\hline Methy & & $1.1 \pm 1.3$ & $0.6 \pm 0.4$ & $1.4 \pm 1.0$ & $0.8 \pm 0.4$ & $1.0 \pm 0.8$ & $0.8 \pm 0.5$ \\
\hline$n$-Nor & & $0.1 \pm 0.1$ & $0.1 \pm 0$ & $0.1 \pm 0.04$ & $0.1 \pm 0.1$ & $0.1 \pm 0.04$ & $0.1 \pm 0.1$ \\
\hline Trichl & & $0.1 \pm 0.1$ & $0.1 \pm 0.1$ & $0.1 \pm 0.1$ & $0.1 \pm 0.1$ & $0.2 \pm 0.2$ & $0.1 \pm 0.1$ \\
\hline Tetrac & & $0.03 \pm 0.01$ & $0.03 \pm 0.02$ & $0.1 \pm 0.02$ & $0.04 \pm 0.01$ & $0.05 \pm 0.05$ & $0.04 \pm 0.03$ \\
\hline$p$-Dic & & $0.1 \pm 0.1$ & $0.1 \pm 0.04$ & $0.1 \pm 0.1$ & $0.15 \pm 0.1$ & $0.1 \pm 0.04$ & $0.1 \pm 0.1$ \\
\hline
\end{tabular}

was observed during early morning (4:00-5:00 am). Overall, the observed high concentrations of BTEX during nighttime can be attributed to the calm atmospheric conditions and lack of photochemical activity.
Measured mean concentrations of BTEX at all six locations were represented in Fig. 4. From the figure, maximum average concentrations of BTEX were found at the industrial location Shiohama, while minimum were 


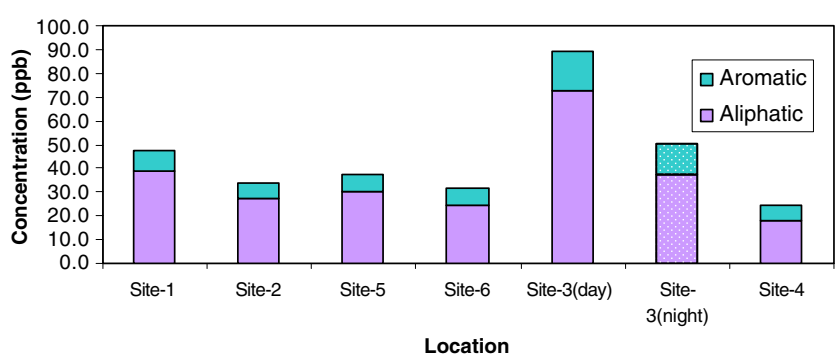

Fig. 2 Total concentrations of VOCs (aliphatic and aromatic portion) in the ambient air at different locations

observed at the residential location Minezawa where the impact of the sources other than vehicles is minimum. Among BTEX, toluene was found most abundant followed by ethyl benzene, benzene, and xylenes. The high concentration of toluene at the industrial location (Shiohama) can be justified by the petrochemical industrial activities at this site. The petrochemical industries at this location include industries such as petrochemical refining and storage, polypropylene, paints, solvent, and varnish.

\section{BTEX correlation}

Correlation analysis helps reveal the possible sources of the aromatic VOCs (Wang et al. 2002; Christensen et al. 1999; $\mathrm{Na}$ and Kim 2001; Brocco et al. 1997). In the present study, Pearson's correlation (Table 3, two-tailed) of the concentrations of BTEX for all six monitoring locations was evaluated. A good correlation between and among the species indicates that their primary source of origin is similar. Indeed, a good mutual correlation was observed between ethyl benzene and xylenes $(r>0.81)$, indicating that they might possibly originate from gasoline source (Baladsano et al. 1998). Benzene showed low $r$ values of correlation with other four species of BTEX at the industrial locations Shiohama and Honmoku, which indicated possible spiking of these VOCs from some additional

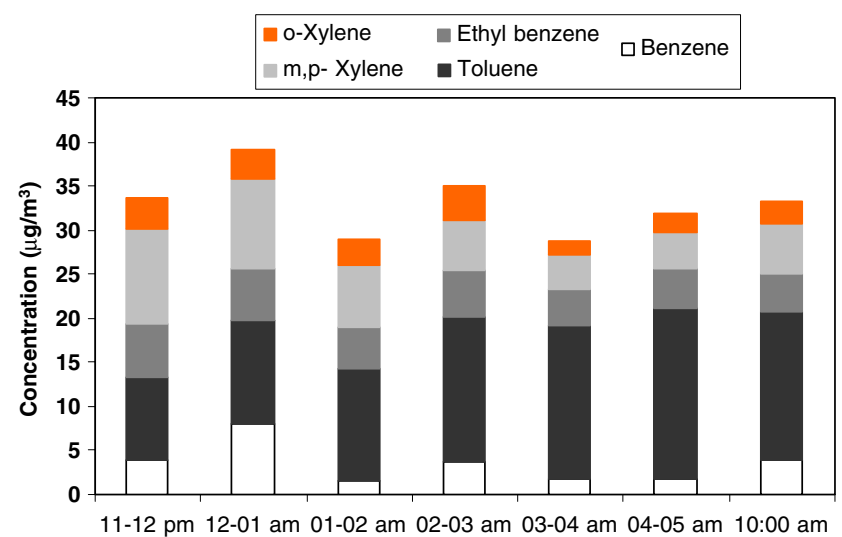

Fig. 3 Temporal variations of benzene, toluene, ethyl benzene, and xylenes (BTEX) at Shiohama (site 3) during nighttime
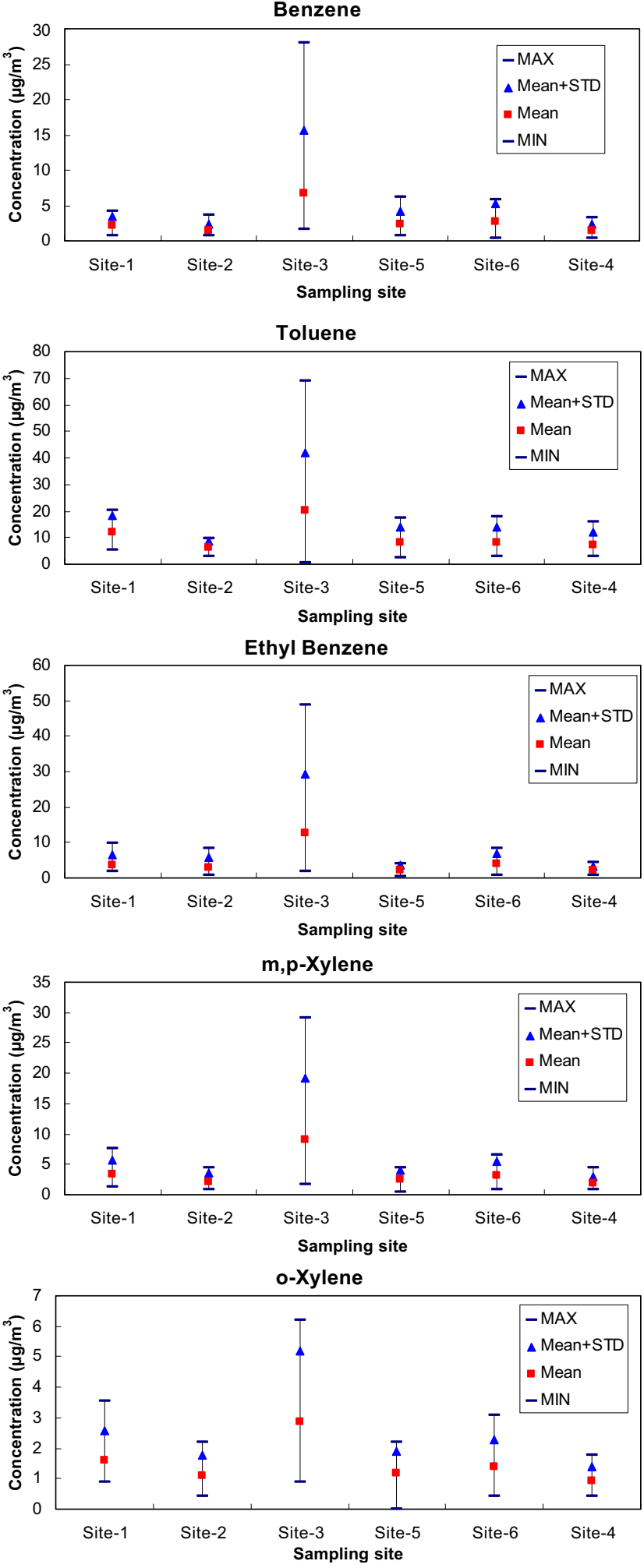

Fig. 4 Concentrations of benzene, toluene, ethyl benzene, and xylenes $(B T E X)$ at the six sampling locations $(n=8)$ 
Table 3 Summary of BTEX correlation coefficients $(r)$ at different sampling sites

\begin{tabular}{|c|c|c|c|c|c|}
\hline & Benzene & Toluene & Ethyl benzene & $m, p$-Xylene & $o$-Xylene \\
\hline \multicolumn{6}{|l|}{ Negishi } \\
\hline Benzene & 1 & & & & \\
\hline Toluene & 0.86 & 1 & & & \\
\hline Ethyl benzene & 0.67 & 0.77 & 1 & & \\
\hline$m, p$-Xylene & 0.80 & 0.92 & 0.93 & 1 & \\
\hline$o$-Xylene & 0.75 & 0.90 & 0.93 & 0.98 & 1 \\
\hline \multicolumn{6}{|l|}{ Honmoku } \\
\hline Benzene & 1 & & & & \\
\hline Toluene & 0.67 & 1 & & & \\
\hline Ethyl benzene & 0.16 & 0.32 & 1 & & \\
\hline$m, p$-Xylene & 0.32 & 0.44 & 0.95 & 1 & \\
\hline$o$-Xylene & 0.30 & 0.34 & 0.92 & 0.97 & 1 \\
\hline \multicolumn{6}{|l|}{ Shiohama } \\
\hline Benzene & 1 & & & & \\
\hline Toluene & 0.09 & 1 & & & \\
\hline Ethyl benzene & -0.20 & -0.02 & 1 & & \\
\hline$m, p$-Xylene & -0.22 & 0.01 & 0.99 & 1 & \\
\hline$o$-Xylene & -0.23 & 0.01 & 0.83 & 0.89 & 1 \\
\hline \multicolumn{6}{|l|}{ Minezawa } \\
\hline Benzene & 1 & & & & \\
\hline Toluene & 0.86 & 1 & & & \\
\hline Ethyl benzene & 0.90 & 0.94 & 1 & & \\
\hline$m, p$-Xylene & 0.85 & 0.92 & 0.92 & 1 & \\
\hline$o$-Xylene & 0.92 & 0.90 & 0.92 & 0.90 & 1 \\
\hline \multicolumn{6}{|l|}{ Sakuragicho } \\
\hline Benzene & 1 & & & & \\
\hline Toluene & 0.75 & 1 & & & \\
\hline Ethyl benzene & 0.81 & 0.81 & 1 & & \\
\hline$m, p$-Xylene & 0.71 & 0.95 & 0.81 & 1 & \\
\hline$o$-Xylene & 0.83 & 0.90 & 0.91 & 0.96 & 1 \\
\hline \multicolumn{6}{|l|}{ Tsurumi } \\
\hline Benzene & 1 & & & & \\
\hline Toluene & 0.62 & 1 & & & \\
\hline Ethyl benzene & 0.60 & 0.82 & 1 & & \\
\hline$m, p$-Xylene & 0.56 & 0.94 & 0.94 & 1 & \\
\hline$o$-Xylene & 0.63 & 0.93 & 0.94 & 0.96 & 1 \\
\hline
\end{tabular}

source in addition to the vehicular source. Since these are industrial sites dominated by petrochemical industries, these industries can be attributed as the additional source. At Minezawa (site 4, residential site), although there were no nearby known point sources of BTEX, significant positive correlation coefficients $(r>0.85)$ were found among the concentrations of BTEX compounds. This indicates that in addition to the limited vehicular source, this residential area receives BTEX from the surrounding areas (Khoder 2007). There is an express highway (Daisan Kehin) with good amounts of traffic, which is located towards east at site 4 , about $500 \mathrm{~m}$ away from the sampling location. This highway also spreads north and southwards near the sampling location. There is a joining point of this highway with two other highways (Yokohama-shindo and Metropolitan Expressway), which is about $500 \mathrm{~m}$ away from the sampling site at Minezawa. These highways might be additional contributors of VOC at this residential location (site 4).

\section{VOC concentration ratios}

Interspecific ratios were taken as an indicator to compare the BTEX emission sources (Khoder 2007; Guo et al. 2007; Kerbachi et al. 2006). Because of the varying reaction rates of VOCs with hydroxyl radical $\left(\mathrm{OH}^{\circ}\right)$, these ratios provide 
Table 4 Toluene/benzene (T/B), $m, p$-xylene/benzene ( $m, p$-X/B), $o$ xylene/benzene $(o-\mathrm{X} / \mathrm{B})$, and $\mathrm{X} / \mathrm{EB}$ concentration ratios at different sampling locations

\begin{tabular}{lccccc}
\hline Location & $\mathrm{T} / \mathrm{B}$ & $\mathrm{EB} / \mathrm{B}$ & $m, p-\mathrm{X} / \mathrm{B}$ & $o-\mathrm{X} / \mathrm{B}$ & $\mathrm{X} / \mathrm{EB}$ \\
\hline Negishi & 6.2 & 1.9 & 1.7 & 0.8 & 1.44 \\
Honmoku & 5.3 & 2.5 & 1.8 & 0.9 & 1.31 \\
Shiohama & 4.5 & 3.8 & 2.7 & 0.9 & 1.24 \\
Sakuragicho & 4.1 & 1.3 & 1.2 & 0.6 & 1.53 \\
Tsurumi & 4.8 & 2.7 & 1.9 & 0.9 & 1.13 \\
Minnezawa & 6.5 & 1.9 & 1.7 & 0.9 & 1.45 \\
\hline
\end{tabular}

information about the difference of origin source in the environment. The abundance of highly reactive VOC species usually decreases in daylight time due to photochemical reactions. On the other hand, the abundance of relatively less reactive species gradually increases during daylight time due to accumulation. Benzene and toluene, with atmospheric lifetimes of 12.5 and 2.0 days, respectively, are relatively stable (Prinn et al. 1987). Xylene ( $m$ xylene), however, has a lifetime of $7.8 \mathrm{~h}$ only and usually does not remain long in the atmosphere (Prinn et al. 1987).

Toluene/benzene (T/B) ratio approaching a value of 1 indicates traffic-originated emission sources, and the value increases with the closeness of the pollution source (Gelencsér et al. 1997). T/B ratio was observed to be high at industrial locations $(>4.5)$. Low xylene/benzene $(\mathrm{X} / \mathrm{B})$ ratios were observed at all locations ( 0.6 to 2.7$)$, which imply aging of the air mass. Highest $\mathrm{T} / \mathrm{B}$ ratio was observed at site 4 (6.5) followed by site 1 (6.2) and site 2 (5.3).

The ratio of xylene/ethyl benzene (X/EB) has been observed to be steady at all three industrial locations (1.241.44 ), which can be attributed to hydrocarbon sources mainly composed of exhaust and refineries (Nelson and
Quigley 1983). Decrease of X/EB ratio can be assigned to photochemical reactions, and the decrease can be a measure of age of the air mass (Nelson and Quigley 1983). The small $\mathrm{X} / \mathrm{B}$ and $\mathrm{X} / \mathrm{EB}$ ratio revealed the fact that photochemical reactions were active. These characteristic ratios are presented in Table 4.

Comparison of benzene and toluene concentrations in industrial areas of different countries

A comparison of benzene and toluene concentrations measured at the industrial areas of different countries is presented in Fig. 5. The overall average concentration of benzene $(0.7 \mathrm{ppb})$ at the industrial location Negishi (site 1$)$ is in agreement with other studies conducted by Kalabokas et al. (2001) for Greek oil refinery, Cheng et al. (1997) for Canadian industrial area, and Gariazzo et al. (2005) for Italian oil refinery. The average concentration of benzene $(2.1 \mathrm{ppb})$ and toluene $(5.2 \mathrm{ppb})$ at the industrial location Shiohama (site 3) is in good agreement with the concentration measured by $\mathrm{Na}$ and $\mathrm{Kim}$ (2001) at a Korean industrial area in which the concentrations were measured as 2.1 and $3.9 \mathrm{ppb}$, respectively. Among these studies, higher benzene concentration (6.8 ppb) was measured by Chang et al. (2005) around a Taiwan petroleum refinery. Various sampling methodologies were used to collect the samples among these studies (canisters sampling method used by Cheng et al. 1997 and Chang et al. 2005; stainless steel container sampling method used by $\mathrm{Na}$ and Kim 2001; adsorbent trap sampling method used by Kalabokas et al. 2001; and automatic analyzer method used by Gariazzo et al. 2005).

Comparison of concentration ratios with other studies

At the industrial location (site 3), in addition to the industrial sources, it appears that toluene was also contributed from
Fig. 5 Comparison of mean values of benzene and toluene in industrial areas of different countries and in the city of Yokohama

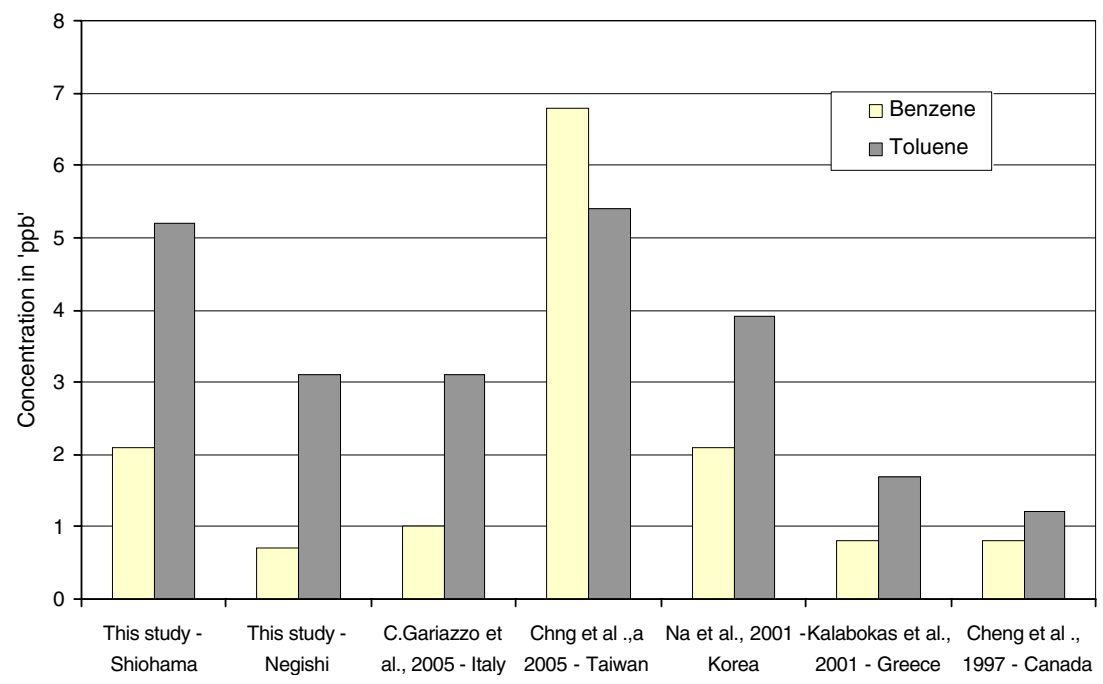


Table 5 Comparison of VOC characteristic ratios at industrial and urban areas in different countries

${ }^{\mathrm{a}}$ The characteristic ratios in other studies were modified by Liu et al. 2008; units converted from parts per billion by volume to parts per billion carbon

\begin{tabular}{|c|c|c|c|c|c|}
\hline \multirow[t]{2}{*}{ City (country) } & \multirow[t]{2}{*}{ Type of area } & \multicolumn{3}{|c|}{ Characteristic ratio } & \multirow[t]{2}{*}{ Reference $^{\mathrm{a}}$} \\
\hline & & $\mathrm{T} / \mathrm{B}$ & $\mathrm{X} / \mathrm{B}$ & $\mathrm{X} / \mathrm{EB}$ & \\
\hline Yokohama (Japan)—Shiohama & Industrial & 4.50 & 2.70 & 1.24 & This study \\
\hline Yokohama (Japan)—Tsurumi & Urban & 4.80 & 1.90 & 1.13 & This study \\
\hline Kaohsiung (Taiwan)—rush hours & Urban & 9.49 & 1.11 & 0.60 & Liu et al. $2008^{\mathrm{a}}$ \\
\hline Kaohsiung (Taiwan)_rush hours & Industrial & 14.2 & 0.92 & 0.38 & Liu et al. $2008^{\mathrm{a}}$ \\
\hline Kaohsiung (Taiwan) & Industrial & 2.30 & 4.05 & 1.30 & Chang et al. 2005 \\
\hline Shizuoka (Japan)—summer & Industrial & 7.70 & 1.61 & 1.16 & Ohura et al. $2006^{\mathrm{a}}$ \\
\hline Shizuoka (Japan) - winter & Industrial & 5.74 & 1.15 & 0.94 & Ohura et al. $2006^{\mathrm{a}}$ \\
\hline Rome (Italy) & Industrial & 3.60 & 1.10 & NA & Gariazzo et al. 2005 \\
\hline Guangxhou (China) & Urban & 1.27 & 1.17 & 4.68 & Wang et al. 2002 \\
\hline Izmir (Turkey) & Urban & 1.59 & 1.09 & 2.22 & Muezzinoglu et al. 2001 \\
\hline Seoul (Korea) & Urban & 6.40 & 2.30 & 3.29 & $\mathrm{Na}$ and $\mathrm{Kim} 2001$ \\
\hline Athens (Greece) & Industrial & 2.13 & 0.90 & 2.30 & Kalabokas et al. 2001 \\
\hline Ulsan (Korea) & Industrial & 1.90 & 1.80 & 4.20 & Kim et al. 2001 \\
\hline Changchun (China) & Industrial & 3.03 & 0.71 & 1.32 & Liu et al. 2000 \\
\hline Thane (India) & Industrial & 0.61 & 0.05 & 1.67 & Mohan Rao et al. $1997^{\mathrm{a}}$ \\
\hline Edmonton (Canada) & Industrial & 1.49 & 0.80 & NA & Cheng et al. 1997 \\
\hline
\end{tabular}

vehicular source, and this might be one of the reasons for the observed high toluene concentration at location Shiohama (site 3). Small X/B ratio (1.90) was observed at the residential site Tsurumi (site 6), which indicated a possibility of aged air mass transported in the study area and was comparable with another study (X/B ratio, 2.30) conducted in Seoul, Korea (Na and Kim 2001). The observed xylene/ethylbenzene ratios at site 3 and site 6 (1.24 and 1.13, respectively) were comparable to results from other studies such as the study conducted at Shizuoka, Japan (Ohura et al. 2006) in which the reported results were in the range of $0.94-1.16$. The characteristic ratios of $\mathrm{T} / \mathrm{B}, m, p$-xylene/benezene $(\mathrm{X} / \mathrm{B})$, and $m, p$-xylene/ethyl benzene $(\mathrm{X} / \mathrm{EB})$ in comparison with that of other studies is shown in Table 5.
Ranking of BTEX with respect to ozone formation potential

Classification of airborne pollutants on a mass concentration $\left(\mu \mathrm{g} / \mathrm{m}^{3}\right)$ basis with respect to human exposure to toxic compounds like benzene is a common practice. It is also of concern to examine the relative importance of these compounds for their role in the production of ozone (Carter 1994) and photochemical smog formation (Carter 1990). The ranking of BTEX can be done with respect to ozone formation potential using Carter's maximum incremental reactivity (MIR). It is popular in the assessment of ozone formation potential of various VOCs (Hung-Lung et al. 2007). Carter's MIR is the amount (in grams) of ozone formed per gram of VOC

Table 6 Ozone formation potential with respect to MIR coefficient in Yokohama, Delhi, and Porto Alegre

\begin{tabular}{|c|c|c|c|c|c|c|c|}
\hline \multirow[t]{2}{*}{ Hydrocarbon } & \multirow[t]{2}{*}{ MIR coefficient } & \multicolumn{3}{|c|}{$\operatorname{VOC}\left(\mu \mathrm{g} / \mathrm{m}^{3}\right)$} & \multicolumn{3}{|c|}{$\mathrm{O}_{3}$ formation potential ${ }^{\mathrm{a}}$} \\
\hline & & Yokohama $^{\mathrm{b}}$ & Delhi $^{\mathrm{c}}$ & Porto Alegre $^{\mathrm{d}}$ & Yokohama & Delhi & Porto Alegre \\
\hline Benzene & 0.42 & 6.7 & 87 & 22 & 3 & 37 & 9 \\
\hline Toluene & 2.70 & 20.1 & 167 & 37 & 54 & 452 & 100 \\
\hline Ethyl benzene & 2.70 & 12.6 & 17 & 20 & 34 & 47 & 54 \\
\hline$m, p$-Xylene & 8.20 & 9.1 & 67 & 36 & 75 & 550 & 295 \\
\hline$o$-Xylene & 6.50 & 2.9 & 35 & - & 19 & 226 & - \\
\hline
\end{tabular}

${ }^{\text {a }} \operatorname{VOC}\left(\mu \mathrm{g} / \mathrm{m}^{3}\right) \times$ MIR

${ }^{\mathrm{b}}$ Location Shiohama

${ }^{\mathrm{c}}$ Khillare et al. (2008)

${ }^{\mathrm{d}}$ Grosjean et al. (1998) 
added to an initial $\mathrm{VOC}-\mathrm{NO}_{\mathrm{x}}$ mixture. It indicates the amount contributed to the ozone formation in the air mass by an individual compound (Carter 1994). MIR coefficients are unitless and intended to be used in relatively high $\mathrm{NO}_{\mathrm{x}}$ conditions.

The ranking of BTEX according to ozone formation potential is given in Table 6. MIR coefficients were adopted from the literatures (Atkinson 1997; Carter 1990, 1994). Based on the MIR scale, $m, p$-xylenes were the most dominant contributors to ozone formation among BTEX, which is in agreement with the observation of Khillare et al. (2008) at Delhi and Grosjean et al. (1998) at Porto Alegre. Toluene is the second largest contributor followed by ethyl benzene.

\section{Conclusion}

A study about the VOC concentrations in the ambient air of Yokohama city was carried out to understand the composition and concentration distribution of VOCs with respect to the type of location. It was observed that the industrial sites might not only encounter emissions from the industrial source but was also influenced by the traffic source in the vicinity. Among the VOC species, high concentrations of aromatic species such as toluene were observed at industrial locations; however, aliphatic fraction was found most abundant. Throughout the study, low concentrations of VOCs were encountered at the residential location. It was evident that in addition to the traffic emissions, industrial activity enhanced the concentration levels of VOCs in the ambient air. During nighttime at industrial location (site 3), high concentrations of benzene and $m, p$-xylene ( 8 and $10.8 \mu \mathrm{g} / \mathrm{m}^{3}$, respectively) were observed at midnight (11:00 pm-1:00 am), and toluene $\left(19.3 \mu \mathrm{g} / \mathrm{m}^{3}\right)$ was observed during early morning (4:005:00 am), which can be attributed to the calm conditions and low dispersion of pollutants in addition to the lack of photochemical activity. T/B ratios were observed to be high at industrial locations $(>4.5)$, and low $\mathrm{X} / \mathrm{B}$ ratios were observed at all the locations (0.6 to 2.7$)$. X/EB ratios were comparatively lower (1.24-1.44) at all three industrial locations, while observed low $\mathrm{X} / \mathrm{B}$ ratios reveals that photochemical reactions were active during daytime. Based on the MIR scale, it was observed that $m, p$-xylenes were the most dominant contributors to ozone formation among BTEX.

Acknowledgments This study was carried out under the funding support of the Japanese Government Scholarship Program (Monbukagakusho). The authors would like to thank the Ministry of Education, Culture, Sports, Science and Technology (MEXT), Government of Japan.
Open Access This article is distributed under the terms of the Creative Commons Attribution Noncommercial License which permits any noncommercial use, distribution, and reproduction in any medium, provided the original author(s) and source are credited.

\section{References}

Atkinson R (1997) Gas-phase tropospheric chemistry of volatile organic compounds 1.Alkanes and alkenes. J Phys Chem Ref Data 26:215-290

Atkinson R (2000) Atmospheric chemistry of VOCs and $\mathrm{NO}_{\mathrm{x}}$. Atmos Environ 34:2063-2101

Baladsano JM, Delgado R, Calbo J (1998) Applying receptor models to analyze urban/suburban VOCs air quality in Martorell (Spain). Environ Sci Technol 32:405-412

Brocco D, Fratarcangelli R, Lepore L, Petricca M, Ventrone I (1997) Determination of aromatic hydrocarbons in urban air of Rome. Atmos Environ 31:557-566

Carter WPL (1990) A detailed mechanism for the gas-phase atmospheric reaction of organic compounds. Atmos Environ 24A:481-518

Carter WPL (1994) Development of ozone reactivity scales for volatile organic compounds. J Air Waste Manage 44:881-899

Cetin E, Odabasi M, Seyfioglu R (2003) Ambient volatile organic compound (VOC) concentrations around a petrochemical complex and a petroleum refinery. Sci Total Environ 312:103-112

Chang CC, Sree U, Lin YS, Lo JG (2005) An examination of 7:009:00 pm ambient air volatile organics in different seasons of Kaohsiung city, southern Taiwan. Atmos Environ 39:867-884

Chattopadhyay C, Samanta G, Chatterjee S, Chakraborti D (1997) Determination of benzene, toluene and xylene in ambient air of Calcutta for three years during winter. Environ Technol 18:211218

Cheng L, Fu L, Angle RP, Sandhu HS (1997) Seasonal variations of volatile organic compounds in Edmonton, Alberta. Atmos Environ 31:239-246

Christensen CS, Skov H, Palmgren F (1999) $\mathrm{C}_{5}$ to $\mathrm{C}_{8}$ non-methane hydrocarbon measurements in Copenhagen: concentrations sources and emission estimates. Sci Total Environ 236:163-171

Coursimault A, Donati J, Viellard H (1995) La pollution automobile due aux hydrocarbures aromatiques monocycliques a Paris. Sci Total Environ 169:17-23

Derwent R (1995) Source, distribution and fates of VOCs in the atmosphere. In: Hester RE, Harrison RM (eds) Volatile organic compounds in the atmosphere. Royal Society of Chemistry, Cambridge, pp 1-15

Finlayson-Pitts B, Pitts J Jr (1986) Atmospheric chemistry: fundamentals and experimental techniques. Wiley Inter-Science, New York

Gariazzo C, Pelliccioni A, Di Filippo P, Sallusti F, Cecinato A (2005) Monitoring and analysis of volatile organic compounds around an oil refinery. Water Air Soil Pollut 167:17-38

Gelencsér A, Siszler K, Hlavay J (1997) Toluene-benzene concentration ratio as a tool for characterizing the distance from vehicular emission sources. Environ Sci Technol 31:2869-2872

Grosjean E, Rasmussen RA, Grosjean D (1998) Ambient levels of gas phase pollution in Porto Alegre, Brazil. Atmos Environ 32:33713379

Guo H, So KL, Simpson IJ, Barletta B, Meinardi S, Blake DR (2007) C1-C8 volatile organic compounds in the atmosphere of Hong Kong: overview of atmospheric processing and source apportionment. Atmos Environ 41:1456-1472

Hanai $Y$ et al (1981) Identification of contaminants in the environmental gas chromatographic analysis. Bulletin of the Institute of 
Environmental Science and Technology, Yokohama National University 7(1):35-41

Hsieh CC, Tsai JH (2003) VOC concentration characteristics in Southern Taiwan. Chemosphere 50:545-556

Hung-Lung C, Jiun-Horng T, Shih-Yu C, Kuo-Hsiung L, Sen-Yi M (2007) VOC concentration profiles in an ozone non-attainment area: a case study in an urban and industrial complex metroplex in Southern Taiwan. Atmos Environ 41:1848-1860

Kalabokas PD, Hatzianestis J, Bartzis JG, Papagianna Kopoulos P (2001) Atmospheric concentrations of saturated and aromatic hydrocarbons around a Greek oil refinery. Atmos Environ 35:2545-2555

Kerbachi R, Boughedaoui M, Bounoua L, Keddam M (2006) Ambient air pollution by aromatic hydrocarbons in Algiers. Atmos Environ 40:3995-4003

Khillare PS, Hoque RR, Agarwal T, Shridhar V, Balachandran S (2008) Spatial and temporal variation of BTEX in the urban atmosphere of Delhi, India. Sci Total Environ 392:30-40

Khoder MI (2007) Ambient levels of volatile organic compounds in the atmosphere of Greater Cairo. Atmos Environ 41:554-566

Kim YP, Na K, Moon KC, Fung MK (2001) Concentrations of volatile organic compounds in an industrial area of Korea. Atmos Environ 35:2747-2756

Kume K, Ohura T, Amagai T, Fusaya M (2008) Field monitoring of volatile organic compounds using passive air samplers in an industrial city in Japan. Environmental Pollution 153:649-657

Lee SC, Chiu MY, Ho KF, Zou SC, Wang X (2002) Volatile organic compounds (VOCs) in urban atmosphere of Hong Kong. Chemosphere 48:375-382

Liu C, Xu Z, Du Y, Guo H (2000) Analyses of volatile organic compounds concentrations and variation trends in the air of Changchun, the northeast of China. Atmos Environ 34:4459-4466

Liu P-WG, Yao Y-C, Tsai J-H, Hsu Y-C, Chang L-P, Chang K-H (2008) Source impacts by volatile organic compounds in an industrial city of southern Taiwan. Sci Total Environ 398:154-163

Mohan Rao M, Pandit GG, Sain P, Sharma S, Krishnamoorthy TM, Nambi KSV (1997) Non-methane hydrocarbons in industrial locations of Bombay. Atmos Environ 31:1077-1085

Muezzinoglu A, Odabasi M, Onat L (2001) Volatile organic compounds in the air of Izmir, Turkey. Atmos Environ 35:753-760

Na K, Kim YP (2001) Seasonal characteristics of ambient volatile organic compounds in Seoul, Korea. Atmos Environ 35:2603-2614
Nelson PF, Quigley SM (1983) The $m, p$-xylenes:ethylbenzene ratio. A technique for estimating hydrocarbon age in ambient atmospheres. Atmos Environ 17:659-662

Ohura T, Amagai T, Fusaya M (2006) Regional assessment of ambient volatile organic compounds in an industrial harbor area, Shizuoka, Japan. Atmos Environ 40:238-248

Olansandan, Amagai T, Matsushita H (1999) A passive sampler-GC/ ECD method for analyzing 18 volatile organo-halogen compounds in indoor and outdoor air and its application to a survey on indoor pollution in Shizuoka, Japan. Talanta 50:851-863

Pfeffer HU, Friesel J, Elbers G, Beier R, Ellermann K (1995) Air pollution monitoring in street canyons in North RhineWestphalia, Germany. Sci Total Environ 169:7-15

Prinn R, Cunnold D, Rasmussen R, Simmonds P, Alyea F, Crawford A, Fraser P, Rosen R (1987) Atmospheric trends in methylchloroform and the global average for the hydroxyl radical. Science 238:945-950

Srivastava A, Joseph AE, Patil S, More A, Dixit RC, Prakash M (2005a) Air toxics in ambient air of Delhi. Atmos Environ 39:59-71

Srivastava A, Sengupta B, Dutta SA (2005b) Source apportionment of ambient VOCs in Delhi city. Sci Total Environ 343:207220

Suleimanov RA (1997) Comparative characteristics of atmospheric emissions from petrochemical and petroleum processing industries. NII Med. Truda I Ekol. Cheloveka, Ufa, Russia. Gig Sanit $1: 8-10$

Wang XM, Sheng GY, Fum JM, Chan CY, Lee SC, Chan LY, Wang ZS (2002) Urban roadside aromatic hydrocarbons in three cities of the Pearl River Delta, People's Republic of China. Atmos Environ 36:5141-5148

World Health Organization (WHO) (1999) Air quality guidelines for Europe. WHO regional publication. European series, World Health Organization, Regional office for Europe, Copenhagen

Yamamoto N, Okayasu H, Hiraiwa T, Murayama S, Maeda T, Morita M, Suzuki K (1988) Continuous determination of volatile organic compounds in the urban atmosphere by an automated gas chromatographic system. J Chromatogr 819:177-186

Yamamoto N, Okayasu HT, Murayama S, Mori S, Hunahashi K, Suzuki K (2000) Measurement of volatile organic compounds in the urban atmosphere of Yokohama, Japan, by an automated gas chromatographic system. Atmos Environ 34:4441-4446 